\title{
CORRESPONDENCE
}

Heat prostration in children with cystic fibrosis

A J Williams, MRCP, and others . . . . . . 297

Cardiac muscle relaxation in

hypothyroidism

J E Sanderson, MRCP.

Accidents on holiday

R Mangnall, FRCSGLAS

Vitamin $A$ and lung cancer

A Sakula, FRCP.

Urinary retention in women

E Barbara Turner, MB.

Outpatient laparoscopic sterilisation

T R M Bristow, FFaRCs................298

T R M Bristow, FFARCS........
Incidence of dermographism

R P Warin, FRCP . . . . . . . . . . . . . . 298

Effects of legal termination on subsequent pregnancy

G Dixon FRCOG, and J A Richardson, FRCSED

Compensation for drug side effects

J A L Gorringe, FRCPED . . . . . . . . . . . . 299

Reducing outpatient attendances

A P Warin, MRCP. . . . . . . . . . . 299

Adverse reactions to practolol

Sir Theo Crawford, FRCPATH.

Carpal tunnel syndrome and tennis elbow

T C Beer, MRCP, and N Memon, MB . . . . 299

Bromocriptine and breast cancer

P A Knowles, MB .............

Eggs and hypercholesterolaemia

$$
\text { .......300 }
$$

A Elkeles, fFrRcsi...............300
High-dose corticosteroids in severe acute asthma

J B Macdonald, MrCP . . . . . . . . . . . 300

Rubella antibody tests in pregnancy

W R G Thomas, FRCPATH............300

Nitrazepam and diazepam

S L O Jackson, MD .................300

Raynaud's phenomenon as side effect of beta-blockers

A J Marshall, MRCP, and others........301

Alternatives to barbiturate hypnotics

D F Scott, MRCPSYCH . ...............301

Child-resistant containers and child poisoning

A W Craft, MRCP, and others.........301

Priorities in the NHS

M H Mills, Ma.................301

Craniopharyngiomas

H B Kennedy, FRCSED, and R J S Smith,

FRCSED . . . . . . . . . . . . . . . . . . 302

Sexual problems clinic

S J G Spencer, FRCPSYCH; J H J Bancroft,

FRCPSYCH, and Lesley Coles.............302

Hazards of modern competitive tennis

E M R Frazer, MD . . . . . . . . . . . . 302

Extrinsic allergic alveolitis

R Penny, FracP..................302

Doctors, contraception, and sterilisation

A R Hill, FRCSED .................... 303

Dosage of neomycin sulphate

$M$ G Thuse, FRCs, and D P Morgan,

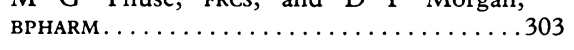

Measles encephalitis during

immunosuppressive treatment

M M Reid, MB, and A W Craft, MRCP.....303

United profession

Sir George Godber, FRCP............. 303

Staffing in the hospital service

S S Chatteriee, FRCP .................303

Pay restraint and the consultant

W W Wilson, FrCs............... 304

Medical manpower and hospital staffing

G I B da Costa, FRCSED . . . . . . . . . . . . . . . 304

An academic backwater?

D J P Gray, FRCGP. .

Bank holidays and the NHS

R H A Campbell, MrCP... . . . . . . . . . 304

Economy in prescribing

P M Morris, MB . ................... 304

Hospital practitioner grade

D Mary Ridout, frCs............... 304

Deputising services

J Armstrong, MB . . . . . . . . . . . . . . . . 305

Apply to ...

J H Bulmer, Frcs. . . . . . . . . . . . 305

Points from Letters Waste in the NHS (C D

Korn); High-dose corticosteroids in severe

asthma (H G J Herxheimer); System, or 2nd MB ?

(J George and F P Rugman); Non-accidental

poisoning and child abuse (M S Dine); The

long and the short of medicine (A A Lewis);

Supporting brassière in mastodynia ( $\mathrm{J} \mathrm{McK}$

Buchanan); Routine preoperative chest radiog-

raphy (J Saperia); Never put off till tomorrow ...

(F M Owers) ......................
Correspondents are urged to write briefly so that readers may be offered as wide a selection of letters as possible. So many are being received that the omission of some is inevitable. Letters should be signed personally by all their authors.

\section{Heat prostration in children with cystic fibrosis}

SIR,-Standard paediatric textbooks note that children with cystic fibrosis are liable to heat prostration. This complication, due to the excessive transcutaneous loss of sodium, has hitherto not been recognised as a real problem in the United Kingdom. We wish to report three cases of hyponatraemic dehydration in children with cystic fibrosis admitted to this hospital in late June and early July this year. The environmental temperature locally has been unusually raised to $10 \mathrm{C}$ above the JuneJuly mean of 1974-5.

Case 1-Male aged 6 years. Presented with a 24-hour history of excessive sweating, anorexia, and weight loss. He had been reluctant to drink. $\mathrm{He}$ was severely dehydrated and hypotensive. Plasma urea $10.8 \mathrm{mmol} / 1(65 \mathrm{mg} / 100 \mathrm{ml})$, plasma sodium $129 \mathrm{mmol}(\mathrm{mEq}) / 1$, and plasma chloride $82 \mathrm{mmol}(\mathrm{mEq}) / \mathrm{H}$. He responded dramatically to intravenous rehydration.

Case 2-Male aged $2 \frac{1}{2}$ years. There had been profuse sweating and pyrexia for three days before admission. He had not eaten during this time but had been drinking water well. He was severely dehydrated. Plasma urea was $9.6 \mathrm{mmol} / \mathrm{l}$ (58 $\mathrm{mg} /$ $100 \mathrm{ml})$ and plasma sodium $124 \mathrm{mmol}(\mathrm{mEq}) \mathrm{l}$. There was a good response to intravenous rehydration.

Case 3-Female aged 2 years. There was a 48hour history of refusal to drink and increasing drowsiness. She had vomited several times. She was severely dehydrated. Plasma urea $11.2 \mathrm{mmol} / 1$ $(67 \mathrm{mg} / 100 \mathrm{ml}$ ) and plasma sodium $125 \mathrm{mmol}$ (mEq) 1. In spite of vigorous rehydration she thereafter made a satisfactory recovery. remained oliguric for approximately 48 hours, but

These three children with cystic fibrosis clearly illustrate the danger of the present unusual climatic conditions. The necessity of salt supplementation in these environmental circumstances should be emphasised to all concerned and, above all, to parents. The

danger of the administration of salt-free glucose solutions also should be borne in mind.

In the past the case has been argued for a safe electrolyte solution that would be commercially available. ${ }^{1}$ In the absence of such a readily available form of electrolyte-glucose solution parents will need explicit instructions on how the salt supplement should be administered.

A J WILliams

JOHN MCKIERNAN

FRANK HARRIS

Alder Hey Children's Hospital,

' British Medical fournal, 1971, 1, 125.

\section{Cardiac muscle relaxation in hypothyroidism}

SIR,-Dr J J Manns and his colleagues state confidently in their recent paper (5 June, p 1366) that combined apex cardiography and phonocardiography can reliably measure the isovolumic relaxation time (IRT) of the left ventricle, based on the assumption that the $O$ point coincides with mitral valve opening. For a long time this assumption has been considered to be dubious if not misleading. In 1965 Tavel et $a l^{1}$ found that the $\mathrm{O}$ point occurred as early as $0 \mathrm{~ms}$ to as late as $52 \mathrm{~ms}$ after the left ventricular pressure and left atrial pressure crossover point and concluded that the $\mathrm{O}$ point "is not simply an expression of mitral valve opening." More recently, in a combined echocardiographic and apexcardiographic study, Prewitt et $a l^{2}$ found that mitral valve opening, measured as the time of separation of the two cusps, preceded the $O$ point in all but three of the 57 patients studied (mean interval $50 \pm 28 \mathrm{~ms}$ ) and that the time of maximum separation of the mitral leaflets also preceded the $\mathrm{O}$ point (mean interval $14 \pm 26 \mathrm{~ms})$. The $\mathrm{O}$ point corresponded more closely to the peak rate of outward wall movement. Dr Manns and his colleagues were, therefore, not measuring an isovolumic relaxation period, although their results do reflect an abnormal relaxation process.

In addition, the effect of ischaemic heart disease cannot be dismissed so lightly. Rubinstein $e t a^{3}$ in 1973 found that the IRT measured by combined echocardiography and phonocardiography was significantly prolonged in patients with ischaemic heart disease. It is unclear how much coincidental ischaemic heart disease was contributing to the results found by $\mathrm{Dr}$ Manns and his colleagues.

Finally, it is surprising that there was no 